\title{
How Does the Academic and Scientific Profile of European Health Ministers and State Secretaries Matter for Informed Decisions?
}

\author{
Bernardo Sousa-Pinto ${ }^{a, b}$ Daniel Martinho-Dias ${ }^{a, b} \quad$ Fernando Araújo $^{a-c}$ \\ Altamiro Costa-Pereira ${ }^{a, b}$ \\ a MEDCIDS - Department of Community Medicine, Information and Health Decision Sciences, Faculty of Medicine, \\ University of Porto, Porto, Portugal; ${ }^{b}$ CINTESIS - Center for Health Technology and Services Research, Porto, \\ Portugal; ${ }^{\complement}$ Centro Hospitalar Universitário São João, EPE, Porto, Portugal
}

\section{Keywords}

Europe · Health policy · Politics · Quality of healthcare

\begin{abstract}
Background: The impact of health politicians' qualifications on healthcare quality has not been widely studied. Objectives: To assess whether academic qualifications and scientific output of European health decision makers correlate with healthcare quality, as well as with other developmental and scientific indices. Methods: We assessed the academic qualifications and scientific output of health ministers and state secretaries of EU member states. Based on the highest academic degree held, we created an academic score for each politician, and calculated the average academic score of each country's health politicians. Associations between the average academic score and public perception of healthcare quality and other developmental and scientific variables were tested by means of simple and multiple linear regression models. Results: Half of the politicians held qualifications in the field of health, followed by economics and management (37\%) and social sciences (35\%). Over the last 10 years, $28 \%$ politicians had authored publications indexed in Web of Science ${ }^{\mathrm{TM}}$, mostly in the field of health. The average
\end{abstract}

academic score of health European politicians was negatively correlated with both public perception of healthcare quality $(\rho=-0.473 ; p=0.011)$ and with countries' gross domestic product (GDP) per capita $(\rho=-0.664 ; p<0.001)$. In a multiple linear regression model, the GDP per capita was independently and negatively associated with the average academic score $(p=0.038)$, but the same was not observed for the public perception of healthcare quality $(p=0.722)$. Conclusions: While correlation does not imply causation, in European countries with higher GDP per capita, health politicians tend to be less qualified.

(c) 2019 The Author(s). Published by S. Karger AG, Basel on behalf of NOVA National School of Public Health

Será que o perfil académico e científico dos ministros e secretários de estado da saúde europeus importa para um processo de decisão informado?

Palavras chave

Europa · Políticas de saúde · Política · Qualidade dos serviços de saúde

\section{KARGER}

karger@karger.com www.karger.com/pjp

Karger Open access (c) 2019 The Author(s). Published by S. Karger AG, Basel on behalf of NOVA National School of Public Health

This article is licensed under the Creative Commons AttributionNonCommercial-NoDerivatives 4.0 International License (CC BYNC-ND) (http://www.karger.com/Services/OpenAccessLicense). Usage and distribution for commercial purposes as well as any distribution of modified material requires written permission.
Bernardo Sousa-Pinto

MEDCIDS - Department of Community Medicine, Information and Health Decision Sciences, Faculty of Medicine, University of Porto

Rua Dr. Plácido da Costa, PT-4200-450 Porto (Portugal)

E-Mail bernardo@med.up.pt 


\section{Resumo}

Contexto: O impacto das qualificações académicas dos decisores políticos em saúde não foi ainda amplamente estudado. Objectivos: Avaliar se o perfil académico e científico dos decisores em saúde europeus se relaciona com a qualidade de prestação de cuidados de saúde, bem como com outros índices de desenvolvimento e científicos. Métodos: Efectuámos um levantamento das qualificações académicas e da produção científica dos ministros da saúde e respectivos secretários de estado dos Estadosmembros da União Europeia. Partindo do grau académico mais elevado alcançado, construiu-se um score académico para cada político e calculou-se o score académico médio para cada país. Foram construídos modelos de regressão linear para avaliar associações entre o score académico médio e a percepção pública da qualidade da prestação de cuidados de saúde e outras variáveis de desenvolvimento e científicas. Resultados: Metade dos políticos apresentavam qualificações académicas na área da saúde, seguindo-se economia e gestão (37\%), e ciências sociais (35\%). Nos últimos 10 anos, $28 \%$ dos políticos publicaram em revistas indexadas na Web of Science ${ }^{\mathrm{TM}}$, a maioria na área da saúde. O score académico médio dos políticos Europeus em saúde correlaciona-se negativamente quer com a percepção pública da qualidade dos cuidados de saúde prestados $(\rho=-0.473 ; p=0.011)$ quer com o Produto Interno Bruto (PIB) per capita ( $\rho=-0.664$; $p<0.001)$ do respectivo país. No modelo de regressão linear múltipla, o PIB per capita demonstrou uma associação negativa independente com o score académico médio ( $p=0.038$ ), mas o mesmo não foi observado para a percepção pública da qualidade da prestação de cuidados de saúde ( $p=0.722)$. Conclusões: Embora correlação não implique causalidade, nos países Europeus com PIB per capita mais elevado, os decisores políticos em saúde tendem a apresentar menos qualificações académicas.

(c) 2019 The Author(s). Published by S. Karger AG, Basel on behalf of NOVA National School of Public Health

\section{Introduction}

Although statesmen education has been a topic of concern, the specific perceived knowledge and skills needed for politicians to be considered successful and competent has changed along with times, and it is still subject of debate [1]. In the health sector, this discussion is particularly critical given the complexity of underlying issues and the vast amount of technical knowledge required to take well-informed and evidence-based de- cisions. In fact, poor health policies and decisions may have costly repercussions in both human and economic terms. In line with this, one may question what might be the ideal combination of study areas in order to become a good health politician. While qualifications in the field of health might be thought as paramount, it is interesting to note that such background was not shared by some of the greatest legislators on that area such as Otto von Bismarck (who laid the bases for the creation of German national health insurance system) or Aneurin Bevan (chief architect of the British National Health Service) $[2,3]$.

In these instances, and following recent discussions and doubts over the background of some European top politicians $[4,5]$, we decided to assess the academic and scientific qualifications of EU health ministers and state secretaries, and investigate whether they varied across European regions or were related to the public perception of healthcare quality in each country, as well as to other developmental and scientific indices.

\section{Materials and Methods}

We obtained information regarding declared academic qualifications of health ministers and secretaries of state (as of August 2016) of EU countries. The search was conducted in governmen$\mathrm{tal} /$ ministerial and politicians' personal websites. We recorded the highest academic degree held by each politician, based on which we created a score to quantify academic qualifications of health politicians; we attributed points for each politician, based on the highest degree held - one point for bachelor's degree, two points for master's degree or postgraduation, and three points for $\mathrm{PhD}$ or equivalent. We then calculated the "average academic score" of each country, corresponding to the average number of points of its ministers and secretaries of state. Additionally, we recorded information on politicians' fields of studies, which were classified in four categories, namely (1) health (including medicine, nursery and biomedical sciences), (2) economics and management, (3) social sciences (including political sciences, philosophy, law, languages and journalism), and (4) others. Qualifications in health management were included both in the health and in the economics and management categories. A field-specific average academic score was also calculated for each country.

Additionally, in order to evaluate scientific production of health politicians, we searched for scientific publications authored by health ministers and secretaries of state over 10 years (20062016), and available in Web of Science ${ }^{\mathrm{TM}}$ as of August 2016. Indexed information such as title, abstract, and keywords of those publications were retrieved and converted or text-mined into $\mathrm{MeSH}$ terms to create a frequency-based word cloud (using the Syn4Data online service; a beta version is available at http://www. syn4data.med.up.pt:8080/Mesh/), so that the subject of the publications could be assessed. The impact factor and rank quartile in the year of publication were also registered.
58

Port J Public Health 2019;37:57-65

DOI: $10.1159 / 000503569$
Sousa-Pinto/Martinho-Dias/Araújo/ Costa-Pereira 
Table 1. Fields of academic qualifications, average academic score $(\min =0 ; \max =3)$, and number of authored scientific publications (in Thomson Reuters Web of Science $\left.{ }^{\mathrm{TM}}\right)$ of EU ( $n=28$ countries) health ministers and state secretaries $(n=78)$

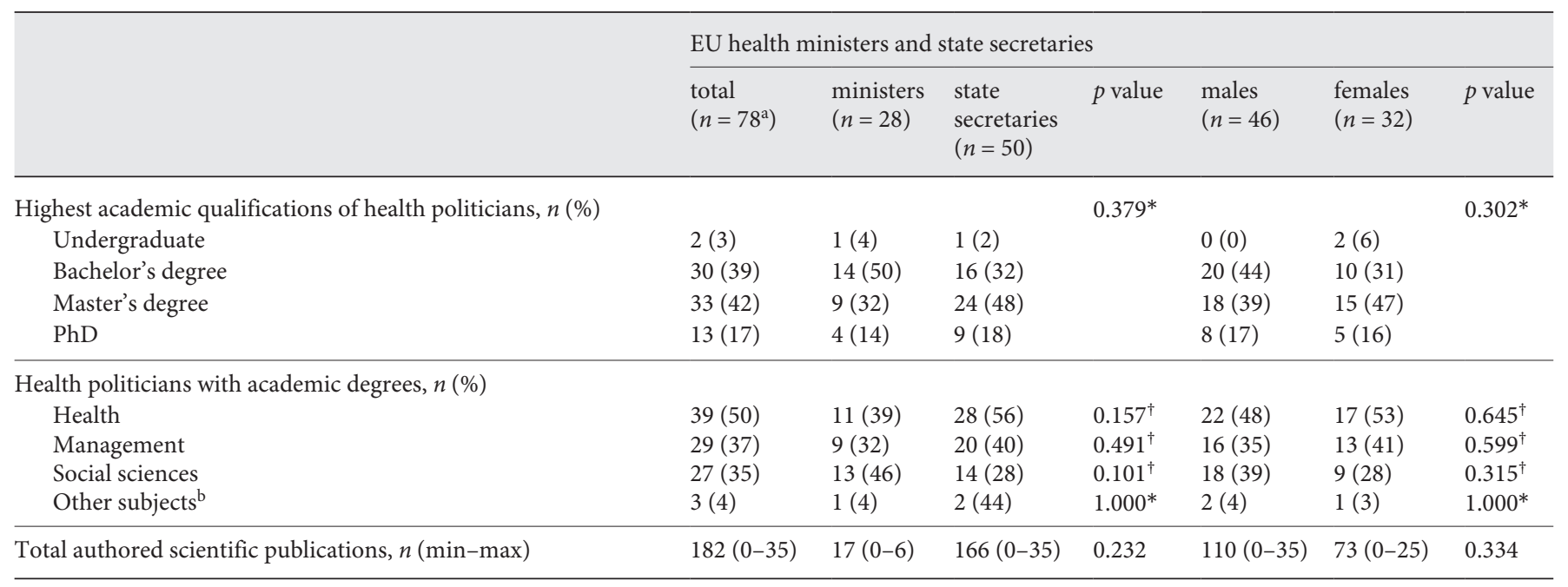

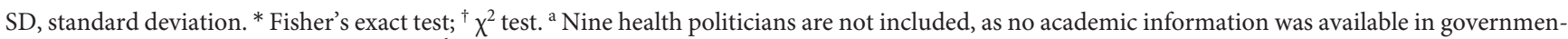
$\mathrm{tal} /$ ministerial or politician personal websites. ${ }^{\mathrm{b}}$ Encompassing engineering, informatics, and music.

We compared average academic scores (both general and fieldspecific) among different European regions - Eastern, Northern, Southern and Western Europe -, as defined by the United Nations Statistics Division (Cyprus, while officially belonging to Western Asia, was included in Southern Europe group) [6]. We also compared general average academic scores in relation to the head of government political group. As of August 2016, the ruling parties of EU countries belonged either to European People's Party (EPP), Progressive Alliance of Socialists and Democrats (S\&D), Alliance of Liberals and Democrats for Europe (ALDE), European Conservatives and Reformists (ECR), and United Left/Nordic Green Left (GUE/NGL). Although the Croatian prime minister was independent, Croatia was included in the EPP group, since most ministers (including the health minister) belonged to the Croatian Democratic Union (HDZ), which is affiliated with the EPP.

We aimed to assess how academic qualifications of EU health ministers and secretaries of state were related to the healthcare quality in each country. In the absence of a gold standard parameter of quality, we opted to assess healthcare quality on the basis of its public perception; thus, we performed a simple linear regression assessing the correlation between countries' average academic score and the percentage of respondents who classified positively (as "fairly good" or "very good") the quality of their healthcare when answering to question QC2 of the Special Eurobarometer 411 ("How would you evaluate the overall quality in of healthcare in our country?") [7]. We compared these results using a simple linear regression assessing the correlation between countries' average academic score and results of the healthcare quality ranking European Health Consumer Index 2015 [8].

Additionally, we performed simple linear regressions to assess the correlation between countries' general average academic score and other developmental and scientific indices, particularly the gross domestic product (GDP) per capita (as assessed by The World Bank; 2015 data [9]); mean years of schooling of adults over

European Health Politicians' Academic Background
25 years old (according to the Human Development Report 2015) [10]; citizens' scientific background (according to the percentage of affirmative responses to question QB4 of the Special Eurobarometer 419 - "Have you ever studied science or technology at school, at university, at college or anywhere else?") [11]; and perceived impact of science on healthcare (based on the percentage of positive responses to question QB2.6. of the Special Eurobarometer 419 - "15 years from now, what impact do you think science and technological innovation will have on health and medical care?") [11].

In order to evaluate which factors were independently correlated with the average academic score, we performed a multiple linear regression with the latter as dependent variable. Independent variables were those for which was found marginal association $(p<0.10)$ by simple linear regression, namely public perception of healthcare quality, and GDP per capita.

Categorical variables were presented as absolute and relative frequencies, while continuous variables were presented as means and standard-deviations. $\chi^{2}$ or Fisher's exact test were used for categorical variables, while Kruskal-Wallis test was used for continuous variables. Correlations were assessed by Spearman coefficients. $p$ values of less than 0.050 were considered statistically significant. All statistical analysis was performed using SPSS, version 22.0 (IBM Corp., Armonk, NY, USA).

\section{Results}

Academic information was available for 78 (89.7\%) out of a total of 87 health ministers and state secretaries. Of the politicians studied, $97.4 \%$ held a bachelor's degree, $57.7 \%$ held a master's degree or postgraduation degree, 


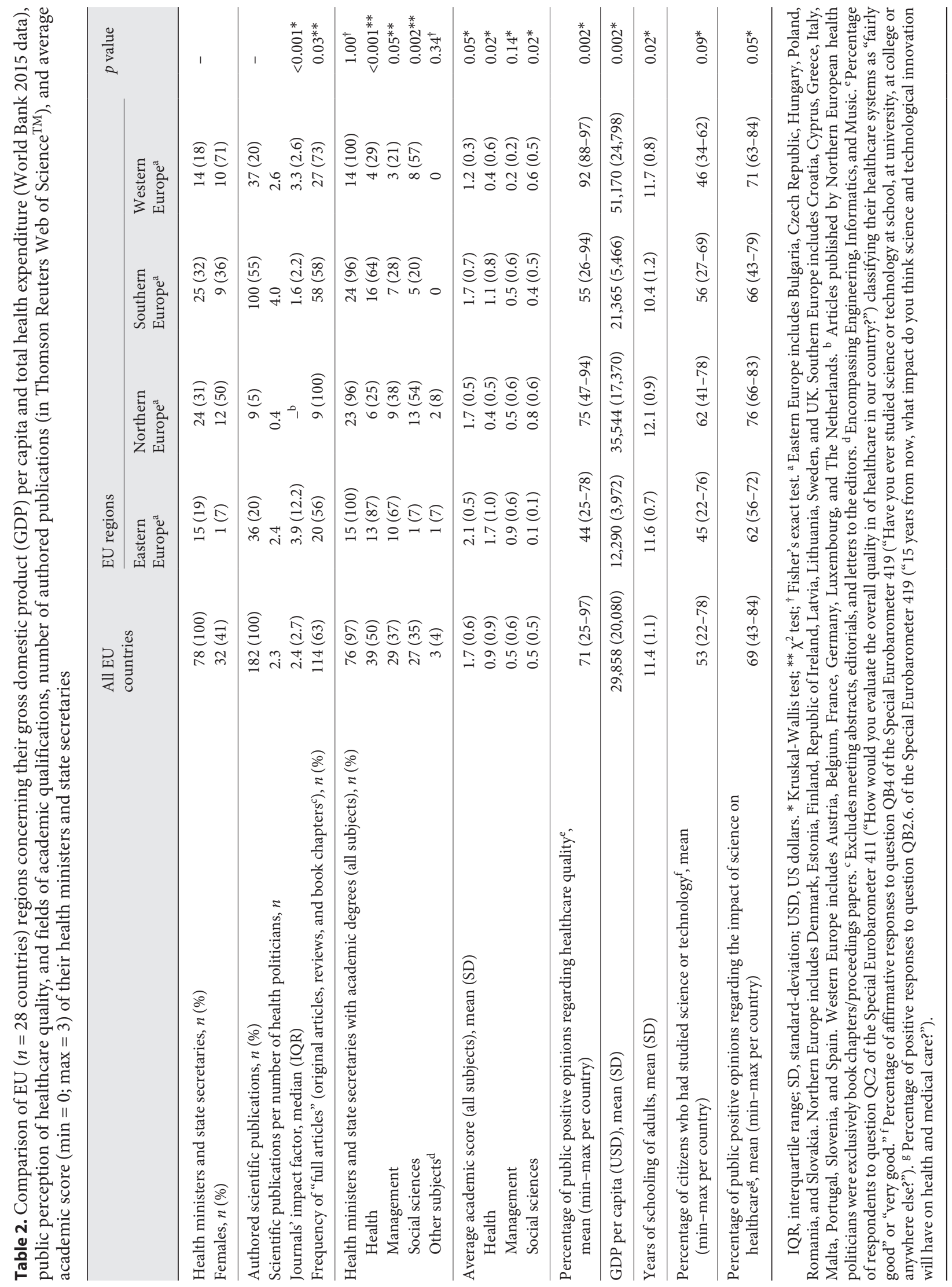

60

Port J Public Health 2019;37:57-65 


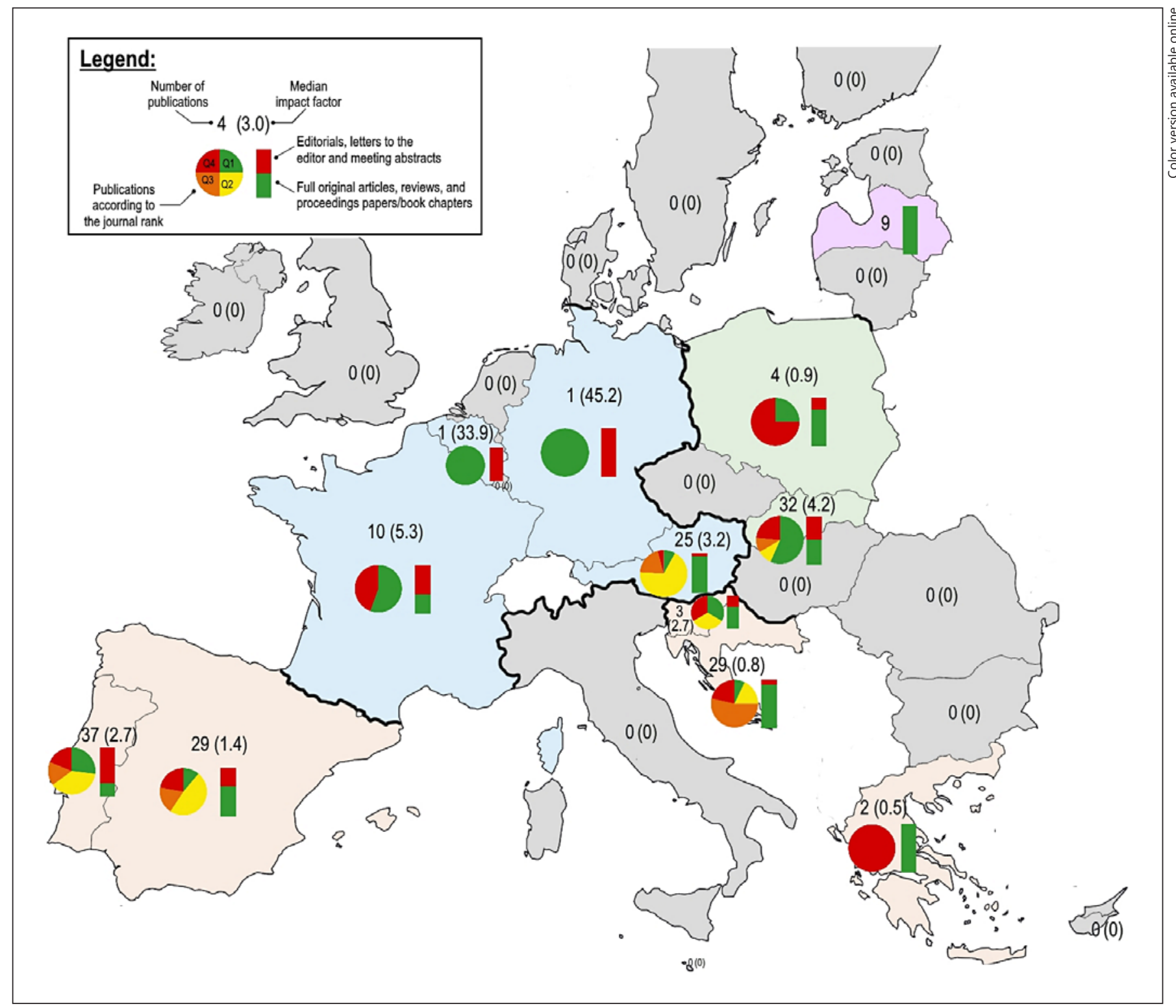

Fig. 1. Number and type of publications per country of the EU, and respective journals' median impact factor and quartile $(\mathrm{Q})$ distribution.

and $16.7 \%$ held a $\mathrm{PhD}$. Half of the politicians held qualifications in the health field, followed by economics and management (37.2\%) and social sciences (34.6\%). Three politicians held academic qualifications in areas other than the aforementioned (Table 1). Thirty-two health politicians were female (41.0\%), with the highest proportion of female politicians in Western Europe (71.4\%) and the lowest percentage in Eastern Europe (6.7\%) (Table 2). There were no gender-related significant differences in

European Health Politicians' Academic Background the degree and field of academic qualifications, or the number of authored scientific publications (Table 1). Accordingly, no significant differences were observed when comparing ministers versus state secretaries (Table 1 ).

Twenty-two (28.2\%) politicians, from 12 different countries, had authored publications indexed in Web of Science $^{\mathrm{TM}}$. A total of 182 different publications were found, with more than half (54.9\%) from Southern Europe, followed by Western Europe (20.3\%), Eastern Eu- 


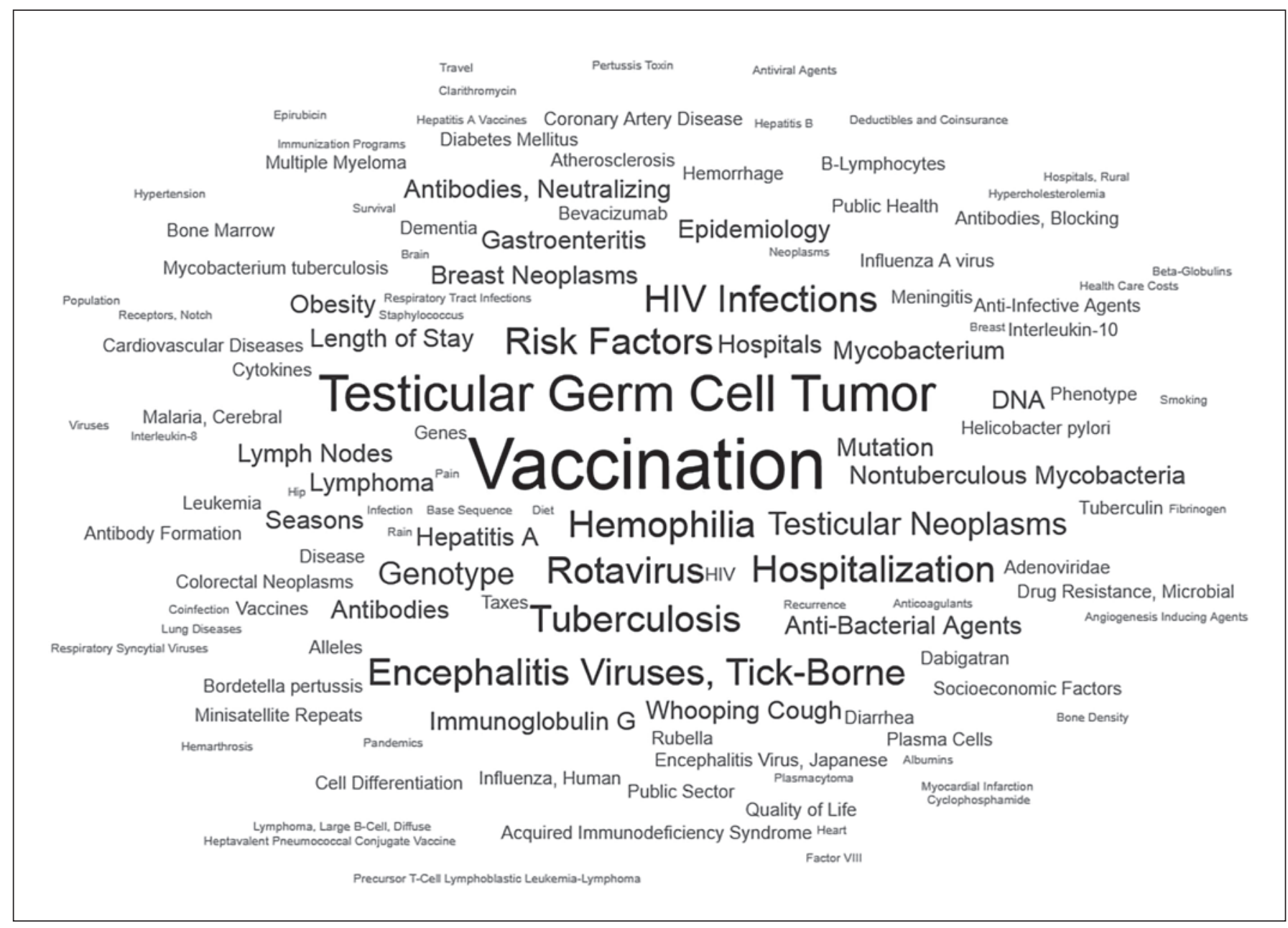

Fig. 2. Scientific production topics of European health ministers and state secretaries. A total of 22 politicians (28\%) have published in Web of Science-indexed journals either research articles or conference papers generating a total of 1,062 keywords. Most frequent research terms are herein represented corresponding to a minimum frequency of 2 , and a total of $53 \%$ of information represented. Terms and cloud generated via Syn4Data application.

rope (19.8\%), and Northern Europe (4.9\%) (Table 2). For these publications, the median journal impact factor was 2.4; most articles were published in journals ranked in the 2nd quartile (31.7\%), followed by the 1 st $(25.7 \%)$, 4 th (22.2\%), and 3rd (20.4\%) quartiles (publication statistics for each country are available in Fig. 1). The subject of these publications can be grasped by the frequency-based word cloud of MeSH terms depicted in Figure 2; most keywords concerned clinical and biomedical terms.

The average academic score for all EU countries was 1.7. The average academic score was significantly different among the distinct European regions, being highest in Eastern Europe (2.1) and lowest in Western Europe
(1.2) $(p=0.046)$ (Table 2$)$. When taking into account only academic qualifications in the health subject, the average academic score also varied significantly with the European regions, being highest in Eastern Europe (1.7) and lowest in Northern Europe (0.4) $(p=0.024)$. In contrast, in the field of social sciences, the average academic score was highest in Northern Europe (0.8) and lowest in Eastern Europe (0.1) ( $p=0.017)$ (Table 2). No significant differences were found when comparing politicians' average academic score according to the different European political groups (average scores: $\mathrm{ECR}=2.1, \mathrm{EPP}=1.8$, $\mathrm{S} \& \mathrm{D}=1.7, \mathrm{ALDE}=1.6 ; \mathrm{GUE} / \mathrm{NGL}=1.3 ; p=0.781)$.
Sousa-Pinto/Martinho-Dias/Araújo/ Costa-Pereira 


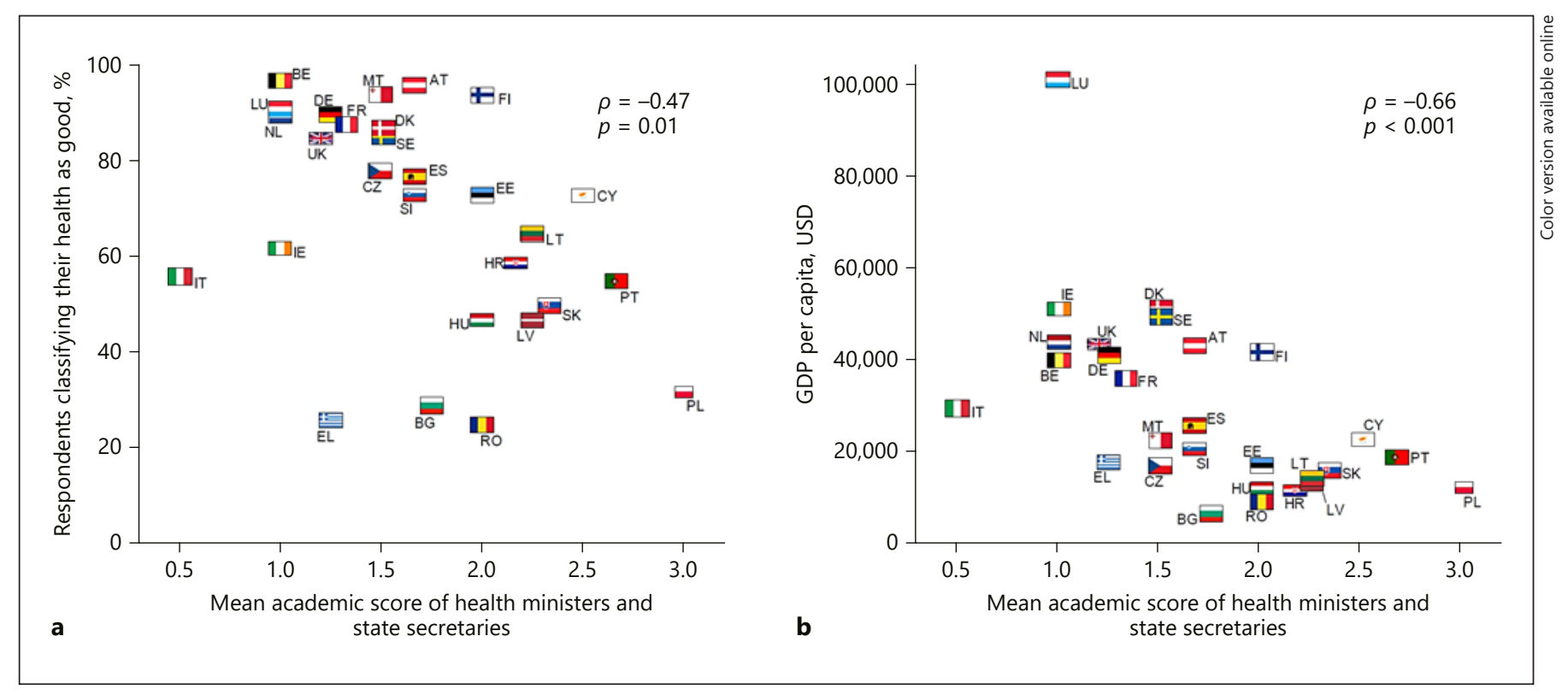

Fig. 3. Correlation between academic qualifications of European health politicians and healthcare satisfaction and gross domestic product (GDP) per capita. Correlation between EU countries' average academic score of health ministers and state secretaries and percentage of respondents to question QC2 of the Special Eurobarometer 411 ("How would you evaluate the overall quality in of healthcare in our country?") classifying their healthcare systems as "good" (encompassing "fairly good" and "very good") (a), and

The average academic score of health ministers and state secretaries was negatively correlated with a positive public opinion regarding the quality of healthcare $(\rho=$ $-0.47 ; p=0.011$ ) (similar results were obtained with the European Health Consumer Index 2015 ranking; $\rho=$ $-0.54 ; p=0.004)$, as well as with the countries' GDP per capita $(\rho=-0.66 ; p<0.001)$ (Fig. 3$)$. In contrast, politicians' average academic score was not significantly correlated with the proportion of female health politicians $(\rho=-0.35 ; p=0.070)$, the average years of schooling $(\rho=$ $-0.11 ; p=0.591)$, citizens' scientific background ( $\rho=$ $-0.10 ; p=0.620$ ) or with the belief on a positive impact of science and technological innovation on health and medical care $(\rho=-0.19 ; p=0.322)$.

Following a multiple linear regression with the average academic score as dependent variable $\left(r^{2}=0.337\right.$; adjusted $r^{2}=0.254 ; p=0.018$ ), the GDP per capita was found to be an independent negative predictor of the average academic score $(p=0.038)$, but the same was not observed for the public perception of healthcare quality $(p=0.722)$ or for the proportion of female health politicians $(p=$ 0.882).

European Health Politicians' Academic Background
GDP per capita (World Bank 2015 data) (b). AT, Austria; BE, Belgium; BG, Bulgaria; CY, Cyprus; CZ, Czech Republic; DE, Germany; DK, Denmark; EE, Estonia; EL, Greece; ES, Spain; FI, Finland; FR, France; HR, Croatia; HU, Hungary; IE, Republic of Ireland; IT, Italy; LT, Lithuania; LU, Luxembourg; LV, Latvia; MT, Malta; NL, The Netherlands; PL, Poland; PT, Portugal; RO, Romania; SE, Sweden; SI, Slovenia; SK, Slovakia; UK, United Kingdom.

\section{Discussion/Conclusion}

In this analysis, we found that most health politicians held qualifications in the field of health. In particular, health ministers and state secretaries appear to be tendentially less qualified in EU countries with higher GDP per capita, where public satisfaction with healthcare quality also appears to be higher.

While half of the qualifications held by politicians were in fields other than health, almost all publications authored by politicians concerned topics of clinical or basic medical research. Comparatively, there were relatively few publications in the domain of public health, health management or subjects other than biomedical sciences. In addition, it is noteworthy to mention that some publications by Western Europe politicians were written after they had become ministers, particularly consisting of Editorials of some highly cited journals [12-14]. This might raise the question of whether politicians from other European regions are being under-represented in such journals, and whether this might contribute to a biased discussion regarding the state of health in Europe. 
This study has important limitations. In particular, its cross-sectional design impairs the ability to draw definite conclusions. In order to allow for results comparison, it would be interesting to see future studies with a longitudinal design and assessing other Ministries than Health (such as the Ministry of Science). Another limitation concerns the fact that scientific publications were searched in a single bibliographic database (Web of Science $^{\mathrm{TM}}$ ); while this facilitates author identification, and ensures comparability of publication metrics, this might result in publication bias, particularly with the exclusion of studies with more relevant topics on a local field (and, therefore, often published in local non-indexed journals). In addition, by limiting the publication search to the last 10 years, we may have missed publications by academicians who have embarked on a political career a longer time ago; this may be particularly problematic if the time span of academicians' political careers is systematically different across distinct European regions. Finally, the assessed regions (based on the United Nations Statistics Division) might be in themselves historically and culturally heterogeneous, as these regions were created with a geographical basis, regardless of political or other affiliations [6].

This study has also some strong points: it is the first study systematically assessing the academic qualifications and scientific production of health politicians, contributing to a discussion on the most important qualities that a politician in the field of health should have. Another strong point concerns the similar results obtained when correlating the average academic score with the public perception of healthcare quality and with a healthcare ranking; this is particularly relevant in the absence of a gold-standard measure of healthcare quality and suggests that public perception of quality is often a better measure than commonly appreciated.

Thus, in this study, we found that, in countries with higher GDP per capita, health ministers and state secretaries tend to be less qualified. These results might be a symptom of a trend to privilege political professional careerism over academic qualifications in ministerial appointments; countries with higher GDP per capita also tend to be those with the oldest established democracies and party systems. In those countries, competition for party prominence may be fiercer, and successful professional politicians might have had less time to dedicate to their own academic qualifications. While correlation does not imply causation, and the cross-sectional design of this study impairs the ability to draw stronger conclusions, our findings raise several questions of po- litical concern. In particular, is the overall quality of the healthcare system more determined by the country's wealth than by its decision-makers' background? Are political decisions in health becoming so complex that the degree and nature of qualifications of politicians matter increasingly less? Does that mean that politicians are mostly expected to play pivotal political, communicational, and negotiation roles, while technical and scientific issues are being increasingly left to regulatory and other specific health agencies? Or does that mean that other entities, such as pharmaceutical companies, patient groups, health professionals' colleges and trade unions, and public opinion/mass media - are increasingly more important in the process of decision-making? If that is the case, then, what is the role left for politicians?

\section{Acknowledgement}

We acknowledge the contributions of António Soares and Júlio Botelho-Souza to the development of Syn4Data tool.

\section{Statement of Ethics}

The authors have no ethical conflicts to disclose.

\section{Disclosure Statement}

The authors declare no conflict of interest.

\section{Funding Sources}

The authors state that this manuscript had no funding sources.

\section{Author Contributions}

Bernardo Sousa-Pinto participated in the study design, data collection, data analysis, and manuscript writing. Daniel Martinho-Dias participated in the development of an online bibliometric tool, data collection, data analysis, and manuscript writing. Fernando Araújo participated in the study design and critical review of the manuscript. Altamiro Costa-Pereira participated in the study design, manuscript writing, and critical review of the manuscript.
Port J Public Health 2019;37:57-65 DOI: $10.1159 / 000503569$
Sousa-Pinto/Martinho-Dias/Araújo/ Costa-Pereira 


\section{References}

1 Murray R. What Makes a Good Politician? Reassessing the Criteria Used for Political Recruitment. Polit Gend. 2015;11(04):770-6.

2 Evans JN. Aneurin Bevan, 1897-1960. In: Evans JN, Howat GM, editors. Great Figures in the Labour Movement. Exeter: Pergamon Press; 1966. pp. 150-66.

3 Steinberg J. Bismarck: A life. 1st ed. Oxford: Oxford University Press; 2012.

4 Paul C. Simon Harris as Minister for Health: the challenge awaits. The Irish Times [Internet]. 2016 Mar 17 [cited 2016 Oct 10]. Available from: http://www.irishtimes.com/lifeand-style/health-family/simon-harris-asminister-for-health-the-challengeawaits-1.2646917

5 Beatrice Lorenzin: dal liceo classico al ministero della Sanità. Giornalettismo [Internet]. 2013 Apr 29 [cited 2016 Oct 10]. Available from: http://www.giornalettismo.com/archives/903331/beatrice-lorenzin-dal-liceoclassico-al-ministero-della-sanita/
6 United Nations Statistics Division [Internet]. Composition of macro geographical (continental) regions, geographical sub-regions, and selected economic and other groupings [cited 2016 Oct 10]. Available from: http://unstats. un.org/unsd/methods/m49/m49regin.htm

7 European Commission. Directorate-General Health and Consumers [Internet]. Special Eurobarometer 411 "Patient Safety and Quality of Care”. European Union; 2014 June. [cited 2016 Oct 10]. Available from: http://ec.europa.eu/ health/patient_safety/docs/ebs_411_en.pdf

8 Björnberg A. Euro Health Consumer Index 2015 [Internet]. Health Consumer Powerhouse; 2016 Jan 26. [cited 2016 Oct 10]. Available from: http://www.healthpowerhouse. com/files/EHCI_2015/EHCI_2015_report. pdf

9 The World Bank. GDP per capita (current US\$) [Internet]. 2015 [cited Oct 10]. Available from: http://data.worldbank.org/indicator/NY.GDP.PCAP.CD
10 United Nations Development Programme. Human Development Report 2015 [Internet]. United Nations; 2015 [cited 2017 Aug 07]. Available from: http://hdr.undp.org/sites/default/files/2015_human_development_report_0.pdf)

11 European Commission. Directorate-General for Research \& Innovation. Special Eurobarometer 419 "Public perceptions of science, research and innovation" [Internet]. European Union; 2014 [cited 2017 Aug 07]. Available from: http://ec.europa.eu/commfrontoffice/ publicopinion/archives/ebs/ebs_419_en.pdf

12 Chioro A, Coll-Seck AM, Høie B, Moeloek N Motsoaledi A, Rajatanavin R, et al. Antimicrobial resistance: a priority for global health action. Bull World Health Organ. 2015 Jul; 93(7):439.

13 De Block M. The difficulty of comparing drug prices between countries. Lancet Oncol. 2016 Apr;17(4):e125.

14 Touraine M, Gröhe H, Coffie RG, Sathasivam $\mathrm{S}$, Juan $\mathrm{M}$, Louardi $\mathrm{H}$, et al. Universal health coverage and the post-2015 agenda. Lancet. 2014 Sep;384(9949):1161-2. 